\title{
Nitrogen and Phosphate Recovery from Source-Separated Urine by Dosing with Magnesite and Zeolite
}

\author{
Suyun Xu*, Liwen Luo, Hongfu He, Hongbo Liu, Lifeng Cui \\ Environment and Low-Carbon Research Center, School of Environment and Architecture, \\ University of Shanghai for Science and Technology, Shanghai 200093, China
}

Received: April 17, 2015

Accepted: May 14, 2015

\begin{abstract}
There is increasing interest in source separation and treatment of urine so as to recover nitrogen and phosphate more efficiently than treating combined wastewater. Although previous studies primarily focused on struvite precipitation for the recovery of phosphorus, the composition of urine changes during storage. The present study compared the precipitation conditions for fresh urine and hydrolyzed urine. The optimal conditions for struvite crystallization were obtained from orthogonal experiment and single-factor optimization. The $\mathrm{pH}$ of fresh urine should be adjusted to around 9.5-10.0 to make the reaction thorough, while this was unnecessary for hydrolyzed urine. To reduce cost, magnesite was selected as an alternative for pure $\mathrm{MgO}$, which presented similar efficiency for phosphate recovery. About $92.4 \%$ of phosphorus and $87.2 \%$ of ammonia-nitrogen were recovered from urine when adding $2.5 \mathrm{~g} / \mathrm{L}$ of magnesite and $375 \mathrm{~g} / \mathrm{L}$ of zeolite to get struvite crystals and nitrogen-rich zeolite as a slow-release fertilizer.
\end{abstract}

\section{Graphical Abstract}

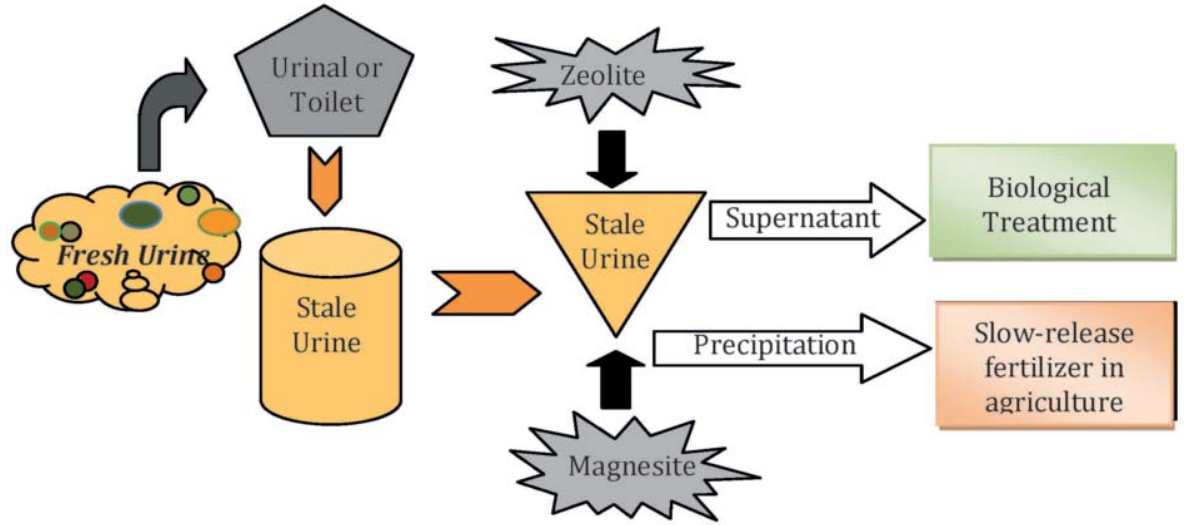

Keywords: urine, struvite, orthogonal experiment, zeolite, adsorption

*e-mail: xusy@usst.edu.cn 


\section{Introduction}

Recent studies have shown that urine separation systems have many advantages over conventional combined wastewater collection system regarding nutrient recovery and pollutant emissions [1]. For example, nitrogen and phosphorous can be recovered to reduce the nutrient load and alleviate the eutrophication situation of accepting waters. It reports that about $80 \%$ of the nitrogen, $50 \%$ of the phosphate, and $60 \%$ of the potassium from domestic wastewater emanates from urine [2]. Ammonium or urea is the indispensable component of fertilizer, which can be acquired from urine $[3,4]$.

Phosphate and ammonia-nitrogen in wastewater can be simultaneously recovered by struvite formation, and the precipitate can be used directly as slow release fertilizers in agricultural production to ease the problem of the shortage for phosphate rock resources [5, 6]. Hanhoun et al. [7] suggested that the method of struvite crystallization precipitation can replace other biochemical technology for phosphate removal and have an application prospect.

However, phosphate recovery was highly associated with $\mathrm{pH}$, the molar ratio of $\mathrm{Mg}: \mathrm{N}: \mathrm{P}$, and reaction time in the solution [8], which may also be affected by the characteristics of wastewater. Actually, urea hydrolysis occurred due to the presence of urease-positive bacteria in toilets and wastewater collection systems, thus the composition of urine changes accordingly [9]. During transportation and storage, urea is hydrolyzed to ammonium and bicarbonate ions, leading to a significant increase of ammonium concentration. To investigate the joint effects of these parameters on struvite formation, an orthogonal test and further comparison between the fresh urine and hydrolyzed urine was carried out in the present study.

Furthermore, the removal rate of ammonia-nitrogen in the struvite precipitation process is limited, and such a high concentration of ammonia-nitrogen in the remaining solution is difficult to be handled via traditional biological processes. Zeolite showed high adsorption capacity for ammonia-nitrogen [10]. Thus it can be used as an adsorbent to further decrease the $\mathrm{N}$ content in the effluent. Meanwhile, adding nitrogen-rich zeolite will have a significant effect of improving fertilizer utilization. However, the applications of zeolite for ammonia removal were mostly adopted in wastewater with relatively low levels of ammonia. The adsorption properties of hydrolyzed urine with a high level of ammonia-nitrogen needs to be investigated.

Therefore, the objectives of this study are as follows:

1) to optimize the dosing ratio of magnesium and operating conditions,

2) to investigate the properties of zeolite adsorption for a high level of ammonia-nitrogen,

3) to testify the synchronous recovery efficiency for phosphate and ammonium.
Table 1. Composition of synthetic human fresh urine.

\begin{tabular}{|c|c|c|c|}
\hline Salt & $\begin{array}{l}\text { Concentration/ } \\
\left(\mathrm{g} \cdot \mathrm{L}^{-1}\right)\end{array}$ & $\begin{array}{r}\text { Concent } \\
\text { (mmo }\end{array}$ & tration/ \\
\hline $\mathrm{CaCl}_{2}$ & 0.44 & $\left(\mathrm{Ca}^{2+}\right)$ & 4 \\
\hline $\mathrm{MgCl}_{2} \cdot 2 \mathrm{H}_{2} \mathrm{O}$ & 0.52 & $\left(\mathrm{Mg}^{2+}\right)$ & 4 \\
\hline $\mathrm{NaCl}$ & 4.8 & & - \\
\hline $\mathrm{Na}_{2} \mathrm{SO}_{4}$ & 2.34 & $\left(\mathrm{SO}_{4}{ }^{2-}\right)$ & 16 \\
\hline $\mathrm{Na}_{3} \mathrm{C}_{6} \mathrm{H}_{5} \mathrm{O}_{7} \cdot 2 \mathrm{H}_{2} \mathrm{O}$ & 0.65 & $\left(\mathrm{C}_{6} \mathrm{H}_{5} \mathrm{O}_{7}{ }^{3-}\right)$ & 2.3 \\
\hline $\mathrm{Na}_{2} \mathrm{C}_{2} \mathrm{O}_{4}$ & 0.02 & $\left(\mathrm{C}_{2} \mathrm{O}_{4}{ }^{2-}\right)$ & 0.15 \\
\hline Creatinine & 1.1 & & - \\
\hline $\mathrm{KH}_{2} \mathrm{PO}_{4}$ & 2.72 & $\left(\mathrm{PO}_{4}^{3-}\right)$ & 20 \\
\hline $\mathrm{KCl}$ & 1.5 & & - \\
\hline $\mathrm{NH}_{4} \mathrm{Cl}$ & 1 & $\left(\mathrm{NH}_{4}^{+}\right)$ & 19 \\
\hline Urea & 25 & & - \\
\hline
\end{tabular}

\section{Material and Methods}

\section{Synthetic Fresh Urine and Hydrolyzed Urine}

Synthetic human fresh urine was prepared according to conventional urological methods [11], whose compositions are presented in Table 1. To get the hydrolyzed urine, the fresh urine was diluted five-fold with deionized water and added $5 \mathrm{~g} / \mathrm{L}$ urease. Fresh urine represented urine composition before urea hydrolysis and precipitation having occurred naturally, while hydrolyzed urine represented urine composition following complete urea hydrolysis and spontaneous precipitation due to associated $\mathrm{pH}$. When completely hydrolyzed, the $\mathrm{pH}$ of hydrolyzed urine was approximately 8.37 , and the concentration of ammonia-nitrogen and phosphate were $90 \mathrm{mmol} / \mathrm{L}$ and 3.54 $\mathrm{mmol} / \mathrm{L}$, respectively.

\section{Experiment Design}

\section{Phosphate Recovery Experiment}

As presented in Table 2, factors selected for the orthogonal experiment $\left(\mathrm{L}_{9}\right)$ were $\mathrm{pH}, \mathrm{n}_{\mathrm{Mg}}: \mathrm{n}_{\mathrm{P}}$, and reaction time. Then, each factor was optimized separately based on the results of the orthogonal experiment. All the tests were carried out using hydrolyzed urine in beakers containing $400 \mathrm{~mL}$ solution with varying conditions and shaken by a rotational speed of $200 \mathrm{rpm} .5 \mathrm{~mol} / \mathrm{L} \mathrm{NaOH}$ and $1 \mathrm{~mol} / \mathrm{L}$ $\mathrm{HCl}$ solutions were used to adjust $\mathrm{pH}$. $\mathrm{MgO}$ was selected as the precipitate agent. The mixture of solid and liquid were separated by centrifuge, following struvite precipitation tests conducted using the orthogonal experiment. After precipitation, the supernatants were analyzed for $\mathrm{pH}$, total phosphorous (TP), and ammonia-nitrogen $\left(\mathrm{NH}_{4}^{+}-\mathrm{N}\right)$ concentrations. 
Table 2. Results of orthogonal test for phosphate recovery.

\begin{tabular}{|c|c|c|c|c|}
\hline \multirow{2}{*}{ No. } & \multicolumn{3}{|c|}{ Factor level } & \multirow{2}{*}{$\frac{\mathrm{PO}_{4}^{3-}-\mathrm{P}}{\text { Recovery } / \%}$} \\
\hline & $\mathrm{pH}$ & $\mathrm{n}_{\mathrm{Mg}}: \mathrm{n}_{\mathrm{P}}$ & $\begin{array}{l}\text { Reaction } \\
\text { time/(min) }\end{array}$ & \\
\hline 1 & 9 & 1.0 & 20 & 89.6 \\
\hline 2 & 8 & 1.8 & 20 & 84.3 \\
\hline 3 & 7 & 1.8 & 30 & 52.3 \\
\hline 4 & 7 & 1.4 & 20 & 43.2 \\
\hline 5 & 9 & 1.8 & 10 & 80.6 \\
\hline 6 & 7 & 1.0 & 10 & 20.1 \\
\hline 7 & 9 & 1.4 & 30 & 96.7 \\
\hline 8 & 8 & 1.0 & 30 & 81.5 \\
\hline 9 & 8 & 1.4 & 10 & 62.8 \\
\hline
\end{tabular}

\section{Ammonia-Nitrogen Removal Experiment}

Firstly, different amounts of zeolite (20-40 mesh), i.e., $125 \mathrm{~g} / \mathrm{L}, 250 \mathrm{~g} / \mathrm{L}, 375 \mathrm{~g} / \mathrm{L}, 500 \mathrm{~g} / \mathrm{L}$, and $750 \mathrm{~g} / \mathrm{L}$ were dispersed into $400 \mathrm{~mL} \mathrm{NH}_{4} \mathrm{Cl}$ solution $(0.1 \mathrm{~mol} / \mathrm{L}$ ammonianitrogen) with magnetic stirring for ammonia-nitrogen adsorption experiment to investigate the characteristics of sorption. The adsorption capacity for ammonia (Eq. 1) was calculated as follows:

$$
q_{t}=V\left(C_{0}-C_{t}\right) / m
$$

...where $q_{t}$ : adsorption capacity, $\mathrm{mg} / \mathrm{g} ; C_{0}$ : the initial concentration of ammonium, mg/L; $C_{t}$ : the solution of ammonium in $t$ reaction time, $\mathrm{mg} / \mathrm{L} ; V$ : the volume of solution, $\mathrm{L}$; and $m$ : the dosage of zeolite in reaction, $\mathrm{g}$.

Secondly, batch mode adsorption isotherm and kinetic studies were carried out at $35^{\circ} \mathrm{C}$. Water samples containing $10,100,250,500,1000$, and $1500 \mathrm{mg} / \mathrm{L}$ of ammonia-nitrogen were prepared for adsorption isotherm experiment. An amount of $25 \mathrm{~g} / \mathrm{L}$ zeolite was introduced into conical flasks. The flasks were placed in a constant temperature oscillator at a rotational speed of $200 \mathrm{rpm}$ for $48 \mathrm{~h}$ to achieve sorption equilibrium. And then approximately $375 \mathrm{~g} / \mathrm{L}$ of zeolite was weighed for adsorption kinetic experiment. Three kinetic models (Eq. 2-4) were used to evaluate the sorption process, i.e. pseudo-first order, pseudo-second order, and intra-particle diffusion. The sample was placed in a $400 \mathrm{~mL}$ solution with $0.1 \mathrm{M}$ ammonia-nitrogen. The solution was stirred at $200 \mathrm{rpm}$. Then the solution was filtered using a $0.45 \mu \mathrm{m}$ filter membrane and the concentrations of ammonia-nitrogen in the filtered solution were measured.

The pseudo-first order model [12, 13]:

$$
\ln \left(q_{e}-q_{t}\right)=\ln q_{e}-k_{1} \cdot t
$$

The pseudo-second order model:

$$
t / q_{t}=1 / k_{2} \cdot q_{e}^{2}+t / q_{e}
$$

The intra-particle diffusion model:

$$
q_{t}=k_{i} \cdot t^{1 / 2}
$$

\section{Synchronous Recovery of $P$ and $N$}

According to the optimum conditions of phosphate recovery gained in the above study, the hydrolyzed urine was diluted and dosed with untreated magnesite, which was carried out in beakers containing $400 \mathrm{~mL}$ solution at a rotational speed of $200 \mathrm{rpm}$. After $30 \mathrm{~min}$ the determined amount of zeolite was applied in the same beaker to adsorb the remaining ammonia-nitrogen. The mixture of solid and liquid was separated and analyzed as described above.

\section{Analytic Methods}

The suspension $\mathrm{pH}$ was measured with $\mathrm{pH}$ meter (Five Easy Plus FE20, METTLER TOLEDO, Switzerland). The phosphate content of the liquid was determined by the molybdenum blue/stannous chloride method. The ammonia-nitrogen was analyzed by the Nessler reagent spectrophotometric method. The precipitation containing struvite was filtered through $0.45 \mu \mathrm{m}$ filter film. To check the formation of struvite crystals, the obtained precipitates were dried at $35^{\circ} \mathrm{C}$ for $48 \mathrm{~h}$ and then analyzed by X-ray diffraction (XRD, Bruker D8 Advance diffractometer with $\mathrm{Cu}$ K $\alpha 1$ radiation, $\lambda=1.5406 \AA$ ), operated at $40 \mathrm{kV}$ and $40 \mathrm{~mA}$ (scanning step: $0.02 \%$ )).

\section{Results and Discussion}

\section{Experimental Condition Optimization for Phosphate Recovery}

\section{Orthogonal Experiment}

The phosphate recovery in this study was based on the formation of struvite, the orthogonal table $\mathrm{L}_{9}$ was designed, and nine groups of experiments were conducted with the results shown in Table 2. Previous research has also investigated the influencing factors for struvite precipitation. Ryu et al. [14] demonstrated that struvite precipitation was highly $\mathrm{pH}$ dependent and the optimum reaction for phosphate recovery was observed at $\mathrm{pH}$ 10.0. Uysal et al. [6] obtained a high purity of struvite precipitation with $\mathrm{n}_{\mathrm{Mg}}: \mathrm{n}_{\mathrm{P}}$ in the range of $0.78-1.78$. In the present tests, the highest phosphate recovery of $96.7 \%$ was achieved under conditions of $\mathrm{pH}, \mathrm{n}_{\mathrm{Mg}}: \mathrm{n}_{\mathrm{P}}$ and reaction times were $9,1.4$, and 30 min, respectively. In addition, to get the most significant factor in the struvite precipitate tests, an analysis of variance was applied, as shown in Table $3[15,16]$. F value is used to represent the impact of corresponding factor and a higher value shows a statistically significant effect. Herein, $\mathrm{pH}$ was the most significant factor affecting the phosphate recovery rate, which corresponded to the previous studies $[15,16]$. While the influence of $n_{M g}: n_{P}$ was less than reac- 
Table 3. Variance analysis for orthogonal test.

\begin{tabular}{|l|c|c|c|c|c|}
\hline \multicolumn{1}{|c|}{ Factor level } & Sum of squares (type III) & df & Variance & F & Sig. \\
\hline $\mathrm{pH}$ & $4,125.3$ & 2 & $2,062.6$ & $1,199.2$ & 0.001 \\
\hline $\mathrm{n}_{\mathrm{Mg}}: \mathrm{n}_{\mathrm{P}}$ & 113.2 & 2 & 56.6 & 32.9 & 0.030 \\
\hline Reaction time & 837.9 & 2 & 419.0 & 243.6 & 0.004 \\
\hline Deviation & 3.4 & 2 & 1.7 & - & - \\
\hline
\end{tabular}

$\mathrm{R}^{2}=0.997$

tion time, it is different from the previous study, which presented that phosphate recovery was highly associated with $\mathrm{n}_{\mathrm{Mg}}: \mathrm{n}_{\mathrm{P}}$ rather than reaction time [17]. This might be related to the difference in phosphate concentrations.

\section{Single Factor Optimization}

To validate the results of orthogonal experiments, three further tests with respective factors were conducted with all other conductions fixed at those determined at optimum. Fig. 1a shows the phosphate recovery first increased but slowly decreased with the $\mathrm{pH}$ increasing. When the initial $\mathrm{pH}$ was set at 8.0 and 9.0, the phosphate recovery rates were $93.8 \%$ and $96.2 \%$, respectively. $\mathrm{pH}$ was associated with the ionic form of $\mathrm{PO}_{4}^{3-}, \mathrm{NH}_{4}^{+}$, and $\mathrm{Mg}^{2+}$ in the reaction. $\mathrm{PO}_{4}^{3-}$ mainly existed in the form of $\mathrm{H}_{2} \mathrm{PO}_{4}^{-}$at a lower $\mathrm{pH}$, while $\mathrm{NH}_{4}^{+}$can be easily converted into free ammonia under alkaline $\mathrm{pH}$. Moreover, the experiment results agreed with the theoretical calculation proven by Wu et al. [18], in which the solubility of struvite crystals is higher in acidic solution and lower at $\mathrm{pH}$ between 8.0 and 11.0, while the solubility of struvite will increase again when $\mathrm{pH}>11.0$. When the hydrolyzed urine was diluted for 5-fold, a steady $\mathrm{pH}$ range of 8.3-8.5 could be reached, which was close to the optimum $\mathrm{pH}$ required for struvite precipitation. Therefore, taking the economic aspect into consideration as well, further $\mathrm{pH}$ adjustment would be unnecessary in the subsequent struvite precipitation process. It was beneficial to reduce additional costs and achieve the goal for phosphate recovery.

Fig. 1b shows the effect of different reaction times on $\mathrm{PO}_{4}^{3-}-\mathrm{P}$ recovery. It demonstrated that the phosphate recovery increased slightly as time increased, and finally was greater than $98.3 \%$ after 25 min reaction time. In addition, Fig. 2a shows that the corresponding characteristic peak of struvite crystals in the sediment was acuter and peak width was narrower when the reaction time extended from $10 \mathrm{~min}$ to $30 \mathrm{~min}$. According to the Scherre equation:

$$
D=R \lambda / \beta \cos \theta
$$

...where $D$ is the crystallite size in the direction perpendicular to the lattice planes, which increases gradually and the crystalline gets better with the decrease of $\beta$, where $\beta$ is the half width at half-maximum of the X-ray diffraction peak in radians. Previous studies illustrated that nucleation and nuclei growth were the two processes in the formation of struvite crystals [19]. Fig. 2 displays the characteristic peaks of struvite occurring after $10 \mathrm{~min}$ and was getting higher as time extended. It indicated the struvite precipitation crystalline was better as time passed [20, 21]. To promote the growth of struvite crystals, the optimal reaction time was extended to appropriately $30 \mathrm{~min}$.

Fig. 1c shows the phosphate recovery rate could reach close to $90 \%$ when $n_{\mathrm{Mg}}: \mathrm{n}_{\mathrm{P}}$ was $1: 1$. It was further confirmed that the ratio of $n_{\mathrm{Mg}}: \mathrm{n}_{\mathrm{P}}$ had little effect on phosphate recovery.
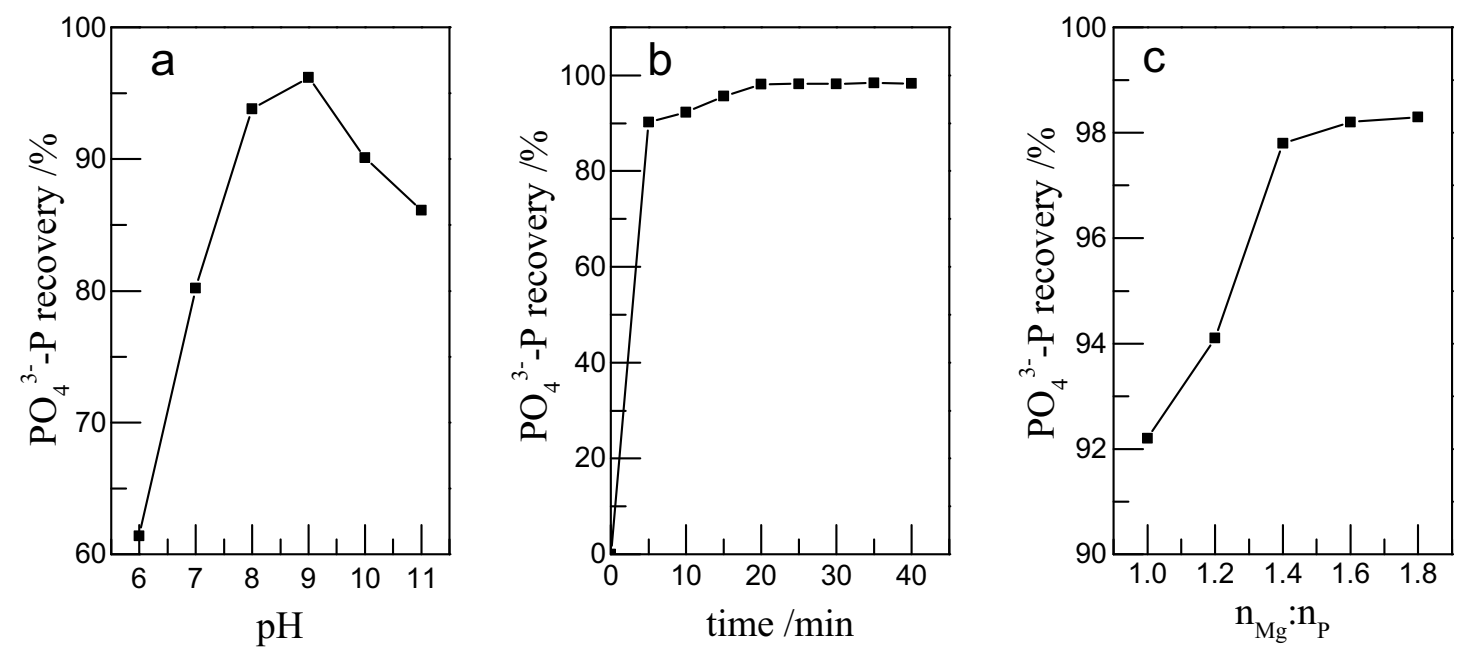

Fig. 1. Influence of the single factor for $\mathrm{PO}_{4}{ }^{3-}-\mathrm{P}$ recovery rate: a) $\mathrm{pH}$, b) reaction time, and c) $\mathrm{n}_{\mathrm{Mg}}: \mathrm{n}_{\mathrm{p}}$. 

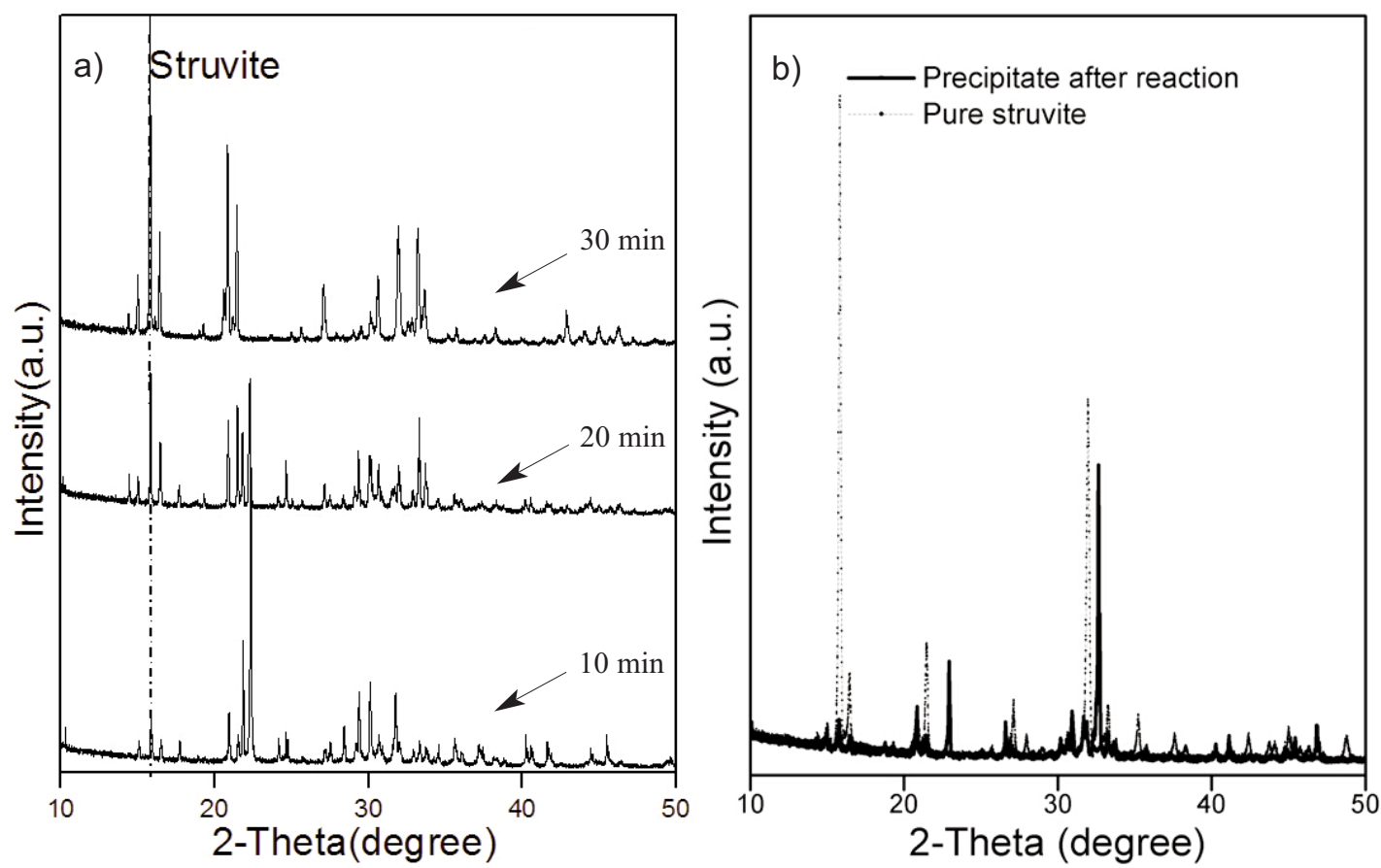

Fig. 2. a) X-ray Diffractograms (XRD) of sediment in different reaction times, and b) XRD of precipitate and pure struvite.

Considering the utilization of Mg-source, the ratio of $\mathrm{n}_{\mathrm{Mg}}: \mathrm{n}_{\mathrm{P}}=1.4: 1$ was chosen for optimum operating conditions.

\section{Ammonia Sorption by Zeolite}

Fig. 3 shows ammonia-nitrogen adsorption by adding different amounts of zeolite. It indicates that the equilibrium absorption capacity of zeolite reduced from $11.0 \mathrm{mg} / \mathrm{g}$ to $4.9 \mathrm{mg} / \mathrm{g}$ when increasing zeolite from $125 \mathrm{~g} / \mathrm{L}$ to 750 $\mathrm{g} / \mathrm{L}$. The maximum adsorption rate was found to be 0.26 mg $\mathrm{NH}_{3}-\mathrm{N} /(\mathrm{g}$-zeolite $\cdot \mathrm{h})$ when $375 \mathrm{~g} / \mathrm{L}$ zeolite was added. The experimental results of the Langmuir and Freundlich adsorption isotherms of zeolite-absorbing ammonia-nitro-

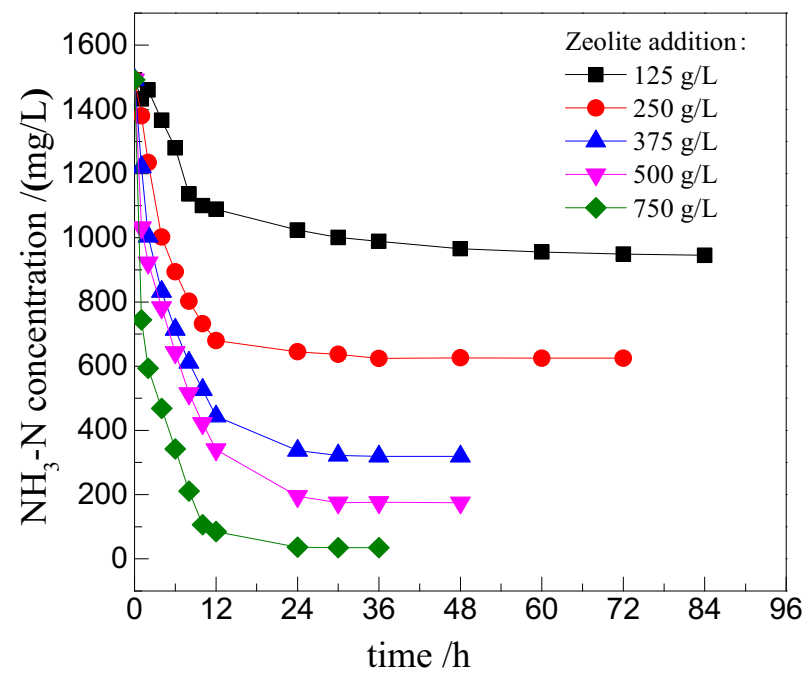

Fig. 3. The adsorption of ammonia-nitrogen with different amounts of zeolite addition. gen show that the correlation coefficient of the Langmuir adsorption was 0.98 , which was higher than that of the Freundlich adsorption. The ammonia-nitrogen adsorption isotherm was well-reproduced to the Langmuir adsorption isotherm model, which meant that the ammonia-nitrogen adsorption type of zeolite involved monolayer coating. The $q_{m}$ and $k$ values in Langmuir's equation were calculated as 13.2 and 0.0065 , respectively. The fitting equation (Eq. 6) of Langmuir adsorption isotherms was:

$$
q_{e}=0.086 C_{e} /\left(1+0.0065 C_{e}\right)
$$

...where $q_{e}$ is equilibrium solid phase concentration $(\mathrm{mg} / \mathrm{g})$, and $C_{e}$ is equilibrium liquid phase concentration $(\mathrm{mg} / \mathrm{L})$. Maximum monolayer adsorption capacity of zeolite was found to be $13.2 \mathrm{mg} / \mathrm{g}$, which is comparable to other research, ranging from 11.5 to $17.45 \mathrm{mg} / \mathrm{g}[22,23]$. This above analysis means that the zeolite has a great adsorption potential of ammonia-nitrogen. Considering that the demand of adsorbent dosage for source separated urine with a high concentration of ammonia-nitrogen increase significantly, the modification of zeolite could be considered in our future study to improve its adsorption capacity.

Meanwhile, the residual ammonia-nitrogen content presented in Fig. 3 shows that the characteristics of ammonianitrogen adsorption of this zeolite was fast adsorption and slow balance, as time passed [24]. In the first stage of adsorption reaction, the ammonia adsorption rate increased. At the $10 \mathrm{~h}$ adsorption time, the adsorption rate slowed down and the concentration of ammonia-nitrogen in the effluent would remain constant.

The kinetics fitting curves and parameters of ammonianitrogen adsorption were compared in Fig. 4. The results obtained from adsorption kinetic experiments were used to 

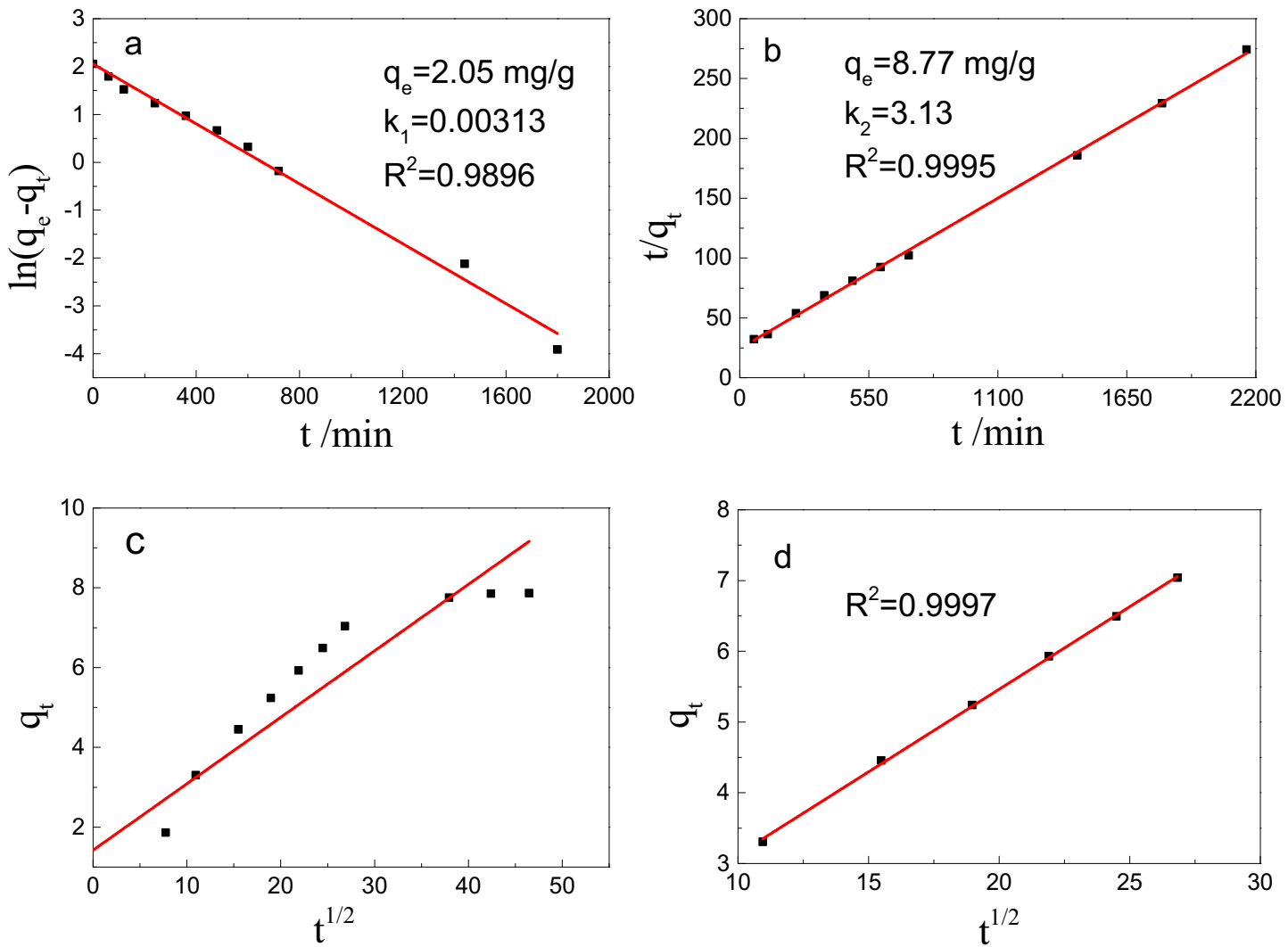

Fig. 4. Kinetics fitting curve of adsorption: a) pseudo-first order models, b) pseudo-second order models, c) intra-particle diffusion models (the whole time), and d) intra-particle diffusion models (2 10h).

study the rate-limiting step in the adsorption process, such as mass transport and chemical reaction processes. Based on the correlation coefficient $\left(\mathrm{R}^{2}\right)$ of three adsorption kinetic models, Fig. 4 shown $\mathrm{R}^{2}$ of the pseudo-second order models was 0.9995 , which is greater than 0.9896 in the pseudo-first order models. So the pseudo-second order kinetic equation had been better used to represent the whole adsorption of ammonia-nitrogen using zeolite. However, the best fitting model for $2 \mathrm{~h}$ to $10 \mathrm{~h}$ adsorption time might possibly be the intra-particle diffusion equation. Fig. $4 d$ shows plots of the linearized form of the intra-particle diffusion equation in Eq. 4 for $2 \mathrm{~h}$ to $10 \mathrm{~h}$ during the sorption process. The $\mathrm{R}^{2}$ for the linear plot of $q_{t}$ against $t^{1 / 2}$ from the intra-particle diffusion equation was greater, to 0.9997 .

\section{Synchronous Recovery of Nitrogen and Phosphate from Urine}

An important disadvantage of treating urine by struvite precipitation is the requirement of an $\mathrm{Mg}$-source for the precipitation process, which is associated with additional costs. To restrain cost, the untreated magnesite (which contained $44 \%$ of $\mathrm{MgO}$ ) was used in the present study for phosphate recovery. The determined dosage of untreated magnesite was added into the hydrolyzed urine (diluted for 5-fold) to get the optimum ratio of $\mathrm{n}_{\mathrm{Mg}}: \mathrm{n}_{\mathrm{P}}=1.4: 1$ as discussed previously. After reacting for $30 \mathrm{~min}$, the phosphate recovery rate was $92.4 \%$. The remaining concentration of ammonia-nitrogen was $890 \mathrm{mg} / \mathrm{L}$, which was lower than theoretical value calculated from struvite precipitation. This indicates that ammonia-nitrogen could not only participate in the reaction for struvite formation, but also be absorbed by natural ore. The comparison of XRD between the precipitate formed in experiment and the pure struvite purchased shows that struvite crystals really generated in the precipitate as shown in Fig. $2 b$. However, the XRD results generated from the precipitation showed a more noisy pattern with reduction in peak size and definition. This indicated the composition of precipitate was complex and the production of struvite crystal was little.

Adsorption ammonia-nitrogen experiment continued by adding zeolite of $375 \mathrm{~g} / \mathrm{L}$ in the liquid after phosphate recovery test. The ammonia-nitrogen removal rate was $83.6 \%$ after reacting for $26 \mathrm{~h}$. In the aggregate, the phosphorus recovery rate and the ammonia-nitrogen removal rate was $92.4 \%$ and $88.4 \%$, respectively. Therefore, the utilization of natural ore has a considerable application prospect and economic value in phosphorus and ammonianitrogen recovery of urine.

\section{Conclusion}

Considering the influence of $\mathrm{pH}$ value on the ion forms of $\mathrm{PO}_{4}^{3-}, \mathrm{NH}_{4}^{+}$, and $\mathrm{Mg}^{2+}$, and the solubility of the reaction product, the optimal $\mathrm{pH}$ value was 8.0 10.0. The optimum conditions for struvite crystallization were: $\mathrm{n}_{\mathrm{Mg}}: \mathrm{n}_{\mathrm{P}}=1.4: 1$, reaction time as $30 \mathrm{~min}$, and no further $\mathrm{pH}$ adjustment 
because the $\mathrm{pH}$ of hydrolyzed urine was suitable for struvite crystallization. Maximum monolayer adsorption capacity was found to be $13.16 \mathrm{mg} / \mathrm{g}$ for zeolite. By dosing $2.5 \mathrm{~g} / \mathrm{L}$ of natural magnesite and $375 \mathrm{~g} / \mathrm{L}$ of zeolite, $92.4 \%$ of phosphorus and $87.2 \%$ of ammonia were recovered from urine. The precipitate containing struvite crystals and nitrogen-rich zeolite could be used as a slowrelease fertilizer, thus this study has considerable practical reference value.

\section{Acknowledgements}

The authors wish to thank the financial supports from Shanghai Municipal Education Commission (slg13028), RTTC China-BMGF 2013, NSFC (51308337) and SKL (PCRRF13007).

\section{References}

1. LIND B.-B., BAN Z., BYD N S. Nutrient recovery from human urine by struvite crystallization with ammonia adsorption on zeolite and wollastonite. Bioresource Technol., 73, (2), 169, 2000.

2. BAN Z., DAVE G. Laboratory studies on recovery of $\mathrm{N}$ and $\mathrm{P}$ from human urine through struvite crystallisation and zeolite adsorption. Environ. Technol., 25, (1), 111, 2004.

3. PRONK W., KON D. Options for urine treatment in developing countries. Desalination, 248, (1-3), 360, 2009.

4. CORNEJO P.K., ZHANG Q., MIHELCIC J.R. Quantifying benefits of resource recovery from sanitation provision in a developing world setting. J. Environ. Manage., 131, 7, 2013.

5. SHU L., SCHNEIDER P., JEGATHEESAN V., JOHNSON $\mathrm{J}$. An economic evaluation of phosphorus recovery as struvite from digester supernatant. Bioresource Technol., 97, (17), 2211, 2006.

6. UYSAL A., YILMAZEL Y.D., DEMIRER G.N. The determination of fertilizer quality of the formed struvite from effluent of a sewage sludge anaerobic digester. J. Hazard. Mater., 181, (1-3), 248, 2010.

7. HANHOUN M., MONTASTRUC L., AZZARO-PANTEL C., BISCANS B., FR CHE M., PIBOULEAU L. Temperature impact assessment on struvite solubility product: A thermodynamic modeling approach. Chem. Eng. J., 167, (1), 50, 2011.

8. TILLEY E., ATWATER J., MAVINIC D. Effects of storage on phosphorus recovery from urine. Environ. Technol., 29, (7), 807, 2008.
9. MAURER M., PRONK W., LARSEN T.A. Treatment processes for source-separated urine. Water Res., 40, (17), 3151, 2006.

10. ZHOU L., BOYD C.E. Total ammonia nitrogen removal from aqueous solutions by the natural zeolite, mordenite: A laboratory test and experimental study. Aquaculture, 432, 252, 2014.

11. GRIFFITH D.P., MUSHER D., ITIN C. Urease. The primary cause of infection-induced urinary stones. Investigative Urology, 13, (5), 346, 1976.

12. HO Y.-S., MCKAY G. Pseudo-second order model for sorption processes. Process Biochem., 34, (5), 451, 1999.

13. GUNAY A., ARSLANKAYA E., TOSUN I. Lead removal from aqueous solution by natural and pretreated clinoptilolite: adsorption equilibrium and kinetics. J. Hazard. Mater., 146, (1-2), 362, 2007.

14. RYU H.D., KIM D., LEE S.I. Application of struvite precipitation in treating ammonium nitrogen from semiconductor wastewater. J. Hazard. Mater., 156, (1-3), 163, 2008.

15. LIU Z., ZHAO Q., WANG K., LEE D., QIU W., WANG J. Urea hydrolysis and recovery of nitrogen and phosphorous as MAP from stale human urine. J. Environ. Sci., 20, (8), 1018, 2008.

16. XU H., HE P., GU W., WANG G., SHAO L. Recovery of phosphorus as struvite from sewage sludge ash. J. Environ. Sci., 24, (8), 1533, 2012.

17. LIU X., HU Z., ZHU C., WEN G., MENG X., LU J. Effect of contact to the atmosphere and dilution on phosphorus recovery from human urine through struvite formation. Environ. Technol., 35, (1-4), 271, 2014.

18. BISHOP P.L. Enhancing struvite crystallization from anaerobic supernatant. J. Environ. Eng. Sci, 3, (1), 21, 2004

19. HANHOUN M., MONTASTRUC L., AZZARO-PANTEL C., BISCANS B., FR CHE M., PIBOULEAU L. Simultaneous determination of nucleation and crystal growth kinetics of struvite using a thermodynamic modeling approach. Chem. Eng. J., 215-216, 903, 2013.

20. LE CORRE K.S., VALSAMI-JONES E., HOBBS P., PARSONS S.A. Impact of calcium on struvite crystal size, shape and purity. J. Cryst. Growth, 283, (3-4), 514, 2005.

21. YU R., GENG J., REN H., WANG Y., XU K. Combination of struvite pyrolysate recycling with mixed-base technology for removing ammonium from fertilizer wastewater. Bioresource Technol., 124, 292, 2012.

22. HALIM A.A., AZIZ H.A., JOHARI M.A.M., ARIFFIN K.S. Comparison study of ammonia and COD adsorption on zeolite, activated carbon and composite materials in landfill leachate treatment. Desalination, 262, (1-3), 31, 2010.

23. ZHANG X., WU W.-Z., WEN D.-H. Adsorption and desorption of ammonia-nitrogen onto natural zeolite. Environ. Chem., 22, (2), 171, 2003 [In Chinese].

24. HUO H., LIN H., DONG Y., CHENG H., WANG H., CAO L. Ammonia-nitrogen and phosphates sorption from simulated reclaimed waters by modified clinoptilolite. J. Hazard. Mater., 229-230, 292, 2012. 
